\title{
The Composition of Women Parliament Members Presence in Local Parliament in Aceh (A Case Study at Provincial Parliament of Aceh Province During the Period of 2014 to 2019)
}

Composition of Women Parliament Members

\author{
Ainol Mardhiah \\ Students of Doctoral Program of Communication Sciences, Faculty of \\ Communication Science, UniversitasPadjadjaran, Indonesia, and Department of \\ Communication Science, Faculty of Social and Politic Science, \\ UniversitasMalikussaleh, Aceh, Indonesia \\ Dadang Rakhmat Hidayat \\ Department of Journalists, Faculty of Communication Science, \\ UniversitasPadjadjaran, Bandung, Indonesia \\ Agus Rahmat \\ Department of Public Relations, Faculty of Communication Science, \\ UniversitasPadjadjaran, Bandung, Indonesia \\ Nuryah Asri Sjafirah \\ Department of Journalists, Faculty of Communication Science, Universitas \\ Padjadjaran, Bandung, Indonesia.
}

\begin{abstract}
Purpose - This study aims to explore the composition of women parliament members in provincial parliament in Aceh Province.

Design/Methodology/Approach - The study which applied qualitative approach. The data were collected through interviews, observations and documentation study.

Finding - The findings show that the DewanPerwakilan Rakyat Aceh (DPRA) (provincial parliament) women representative are not in line with the order of election Regulation No. 12 the year 2003 which state should be an "affirmative action" or reaches about $30 \%$ of total members. In addition, ironically that women are not playing important and strategic roles, such as a chairman, deputy chairman, in each commission, discussion division, budgeting division, and regulation division. The biggest challenge of women parliament members in campaigning their rights and responsibilities at the parliament so that they would be improved in
\end{abstract}

(C) Ainol Mardhiah, Dadang Rakhmat Hidayat, Agus Rahmat, Nuryah Asri Sjafirah. Published in the Emerald Reach Proceedings Series. Published by Emerald Publishing Limited. This article is published under the Creative Commons Attribution (CC BY 4.0) licence. Anyone may reproduce, distribute, translate and create derivative works of this article (for both commercial and noncommercial purposes), subject to full attribution to the original publication and authors. The full terms of this licence may be seen at http://creativecommons.org/licences/by/4.0/legalcode

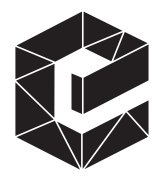

Emerald Reach Proceedings Series Vol. 1 pp. $295-301$ Emerald Publishing Limited 2516-2853 DOI 10.1108/978-1-78756-793-1-00076 
Proceedings of MICoMS 2017 quality and capacity, as well communication and personal knowledge. Furthermore, building stronger linkages internally and externally (political parties, fraction, and all other parliament members), and (stakeholders, peer groups, NGOs, academics, expert etc).

Practical implications - The solutions offered in this paper can be of concern to all parliamentarians to be able to provide equal opportunities for women legislative members in a strategic position in parliament.

Originality/Value - In addition to increasing the theoretical understanding of the political communication and the importance of the presence of the women in the local parliament.

\section{6}

All papers within this proceedings volume have been peer reviewed by the scientific committee of the Malikussaleh International Conference on Multidisciplinary Studies (MICoMS 2017).

\section{Introduction}

Women's participation in politics in the legislature of a local parliament is an attempt to communicate themselves in the public sphere in their social role. Therefore, women become legislators and are in parliament as a form of their participation in political development. As the female legislators in the Local House of Representatives, they must perform their duties and functions in a normative manner; functions of legislation, budgeting and supervision. Therefore, communication of women legislators becomes important to be examined in the coordination of their actions to achieve the achievement of these legislative duties and functions.

Members of the Local House of Representatives, as one of the groups who take part in supra structures in the regions, the members of the council become an extension of the community that plays a role to accommodate the aspirations, voice from below and channel the aspirations to the government so that the demands of the community become a concern and become part of political decisions and with good accommodation of all the interests of society, the public will be able to participate optimally in political development.

The Acehnese women's activities as legislators in Aceh's House of Representatives as their organizational agent in carrying out political development are interesting to be reviewed in its relation to the Acehnese culture and also to the Islamic Shari'a in Aceh which still differ on the position of women as leaders. Based on the results of the 2014 election, there were 11 female legislators from 81 members of the DPRA or about $13.6 \%$. The results of the Aceh Independent Election Commission (KIP) have not yet fulfilled the $30 \%$ quota of women's representation in the local parliament and this has not been in line with the mandate of the Election Law No.12 of 2003.

Looking at the background of the 11 female legislators in the local parliament of Aceh in the period of 2014-2019, they come from diverse professional backgrounds, including: legislative members in the previous district/city, the incumbents in DPRA for their second period, housewives and private sector workers (data in the secretariat of DPRA, 2017). The representation of women legislators in Aceh's parliament is one of the manifestations of their participation, involvement and existence in political development in Aceh.

It is not easy when women are in the political sphere. There are many challenges and barriers in the politics of Aceh. The challenges are both internal and external in nature. Internally, for example, Acehnese women are less highly motivated to attend this room, their lack of capacity in politics, lack of experience in this field, as well as their low awareness to actively engage in political participation. Further, the externals may include social, economic, cultural, political and religious factors. This condition causes a very few numbers of Acehnese women who are in the political world (Observation, 2017). 
The presence of women in the political sphere is variously interpreted. Culture, social systems, political systems, and poverty issues are still challenging in the participation of women in politics. A more strategic ones are needed to change the conditions. Entering a strategic territory should mean stepping into a friendly alternative decision making to women. Among the ways is by electing eligible women into the power and legislation. For women legislators, this institution becomes the place where they run the mandate of their constituents, where they channel the aspirations of the people.

As a legislator, the eleven Acehnese female legislators must present themselves as

Composition of Women Parliament Members

297 political actors, dialogue to convey political messages in a straightforward, effective way, both verbally and non-verbally, both legislatively, within their political parties and in the community (constituents). The behavior of political communication is obtained through the process of interaction (dialog), experience, tasks, responsibilities and their functions in the legislature, and from the process of understanding, meaning and knowledge of legislators themselves, in addition to their ability to accommodate, capture the aspirations of the community.

Members of Acehnese women legislators are required to be able to fight for the emergence of policies that favor the interests of the people and, especially, the interests of women, through the process of argumentation, and also negotiations. Without these abilities, women in parliament will only be seen as a compliment and become accessories for a male legislator who are, indeed, hold the prominent role.

Furthermore, female legislators are also required to have communication competence. Jablin and Sias (in Indriastuti, 2015: 85) define communication competence as the number of abilities a communicator possesses to use in the communication process, which emphasizes knowledge and ability. In addition, Boserup says that: "education will improve women's status, abilities, and skills" (1984: 129).

However, the current problem in local parliaments is that the representation of women in the local parliament of Aceh at the provincial level is still not in accordance with the affirmative action law, hereinafter seen from the composition of female legislators in the Aceh's House of Representatives does not occupy in strategic positions either as chairman, deputy chairman, special committee, in the Financial departments, legislative-affairs departments, in so that women legislators must work harder to fight for women's rights in fulfilling their obligations. Based on this problem, the researcher tries to explore more deeply about how the composition of female legislators in the local parliament of Aceh in carrying out their political communication activity as the member of legislative in Aceh's House of Representatives of 2014-2019 period.

\section{Methods}

The research employed a case study method. Case studies are a common way of conducting a qualitative inquiry (Stake in Denzin and Lincold, 2005: 443). A case study research is neither new nor essentially qualitative. A case study is not a methodological choice, but a choice of what to study.

Data was collected by interviews, observation and documentation studies. Research location was in Aceh's House of Representatives.

\section{Results and discussion}

The presence of women as legislators in the local parliament of Aceh provides its own colors and dynamics within this parliament; the challenges and opportunities of women's presence can be seen from their composition within this local parliament. Opportunities merged when women were able to give color in their representation in this legislature, the representation 
Proceedings of MICoMS 2017

\section{8}

of women in parliament as a form of democracy. The challenge was that women have to work extra hard in the midst of male domination, improving their communication competence (knowledge, skills, and attitudes) and worked harder in changing the mindset with already powerful patriarchal perspectives.

The results included the data on elected female legislators in Aceh's House of Representatives and their composition in the local parliament of Aceh for the period of 2014-2019.

The table shows eleven legislative members in Aceh for the period of 2014-2019 from different electoral districts in Aceh. Judging from the number of elected female legislators, there are only $13.6 \%$ of women representatives for Aceh's women; 11 out of 81 council members in the Aceh House of Representatives. Referring to the Election Law No. 12 of 2003 revealed that women's representation in Aceh has not been compatible with the Affirmative Action term, meaning that women's representation in the local parliament of Aceh has not reached $30 \%$ of the quota.

Based on the data, the representation of women as members of the legislature is represented by local parties (PNA, PA) and national parties (Golkar, Gerindra, PAN, Nasdem); 6 parties out of 15 parties were successfully represented by women in the election of legislative members in the Aceh People's Representative Council in period of 2014-2019. In quantity, this number shows a better number than the previous period. In the 2004-2009 election period women who attended the House of Representatives in Aceh were only 3 women. And, it was the same case in the period of 2009-2014 as the number of female legislators was as many as 4 women. The period of 2014-2019 shows better figures with an increase of nearly $200 \%$ of the total number of women legislators in this local parliament.

Table 1 also depicts the ironic reality of female legislators in Aceh House of Representative that reflected by their position in commissions; most of them are merely a member of a commission and there is only one person who becomes secretary of commission in Education, Science and Technology. Women in this parliament do not occupy strategic positions within any commission. Table 1 below shows the composition of legislators in Aceh's House of Representatives (DPR).

Table 2 above shows that the eleven female legislators in the Aceh legislature are only members of existing commissions, whereas the position of chairman, vice chairperson, secretary are dominated by male legislators. Further, it also turns out that this group of

\begin{tabular}{rllllll}
\hline No & Name & Party & $\begin{array}{l}\text { Position in } \\
\text { Commission }\end{array}$ & $\begin{array}{l}\text { Deliberation } \\
\text { body }\end{array}$ & $\begin{array}{l}\text { Financial } \\
\text { body }\end{array}$ & $\begin{array}{l}\text { Legislation } \\
\text { body }\end{array}$ \\
\hline 1. & Darwati A. Gani & PNA & Member & Member & - & - \\
2. & Nurlelawati, S.Ag & Golkar & Member & Member & Member & - \\
3. & Hj. Fauziah, H.M.daud., S.Pd & Golkar & Member & Member & - & - \\
4. & drh. Nuraini Maida & Golkar & Member & - & - & - \\
5. & Kartini Ibrahim & Gerindra & Member & - & - & Member \\
6. & Hj.Ummi kalsum & PA & Member & - & - & - \\
7. & Siti Nahziah & PA & Secretary & - & Member & - \\
8. & Dra.Hj.Mariati MR.,M.Si & PA & Member & Member & - & - \\
9. & Ismaniar & PAN & Member & - & - & - \\
10. & Ir. Hj.Liswani & PAN & Member & Member & - & Member \\
11. & Ir. Hj. Fatimah & Nasdem & Member & Member & - & -
\end{tabular}

Source: The secretariat of DPR Aceh, 2017.
Table 1.

Composition of Female Members in Aceh Local House of Representatives 


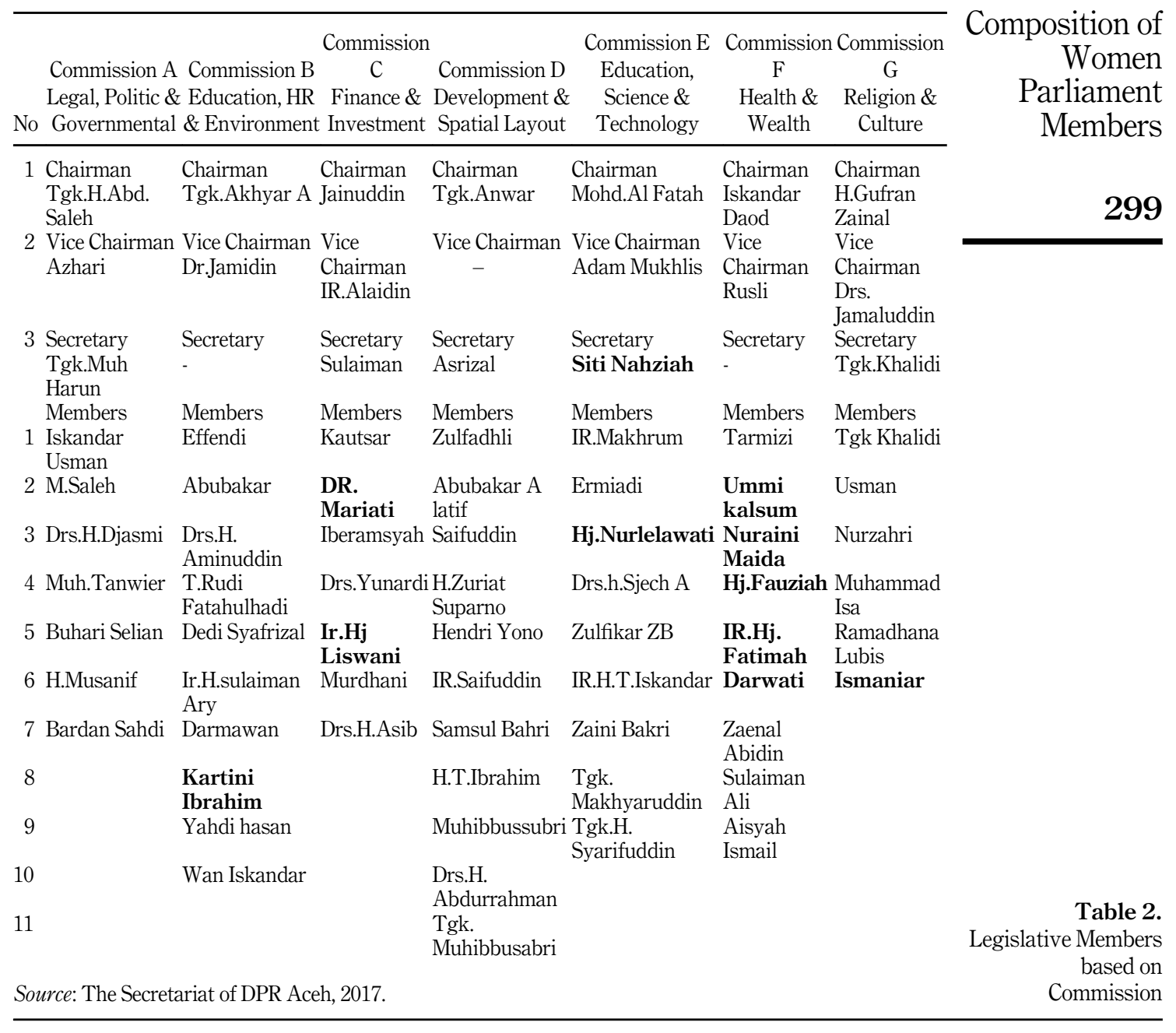

women tends to be in commissions that are very feminist, which revolves around the field of health, welfare, education, science, and technology.

The same case was observed at the deliberate, financial, and legislative bodies; there was no female legislator who became Chairman, vice chairman and secretary were all held by men. And the membership is also dominated by man; there are two female legislators who are not included in the membership in bodies of deliberate, financial, and legislative in board fittings. This is unfortunate given that female legislators should be able to contribute more to this local parliament;it is expected that women legislative members are the decision makers or policies to be decided, they are not the ones who merely accept the decisions and who will run the policy, but they also decide the policy to be enforced.

Women legislators in the local parliament of Aceh will continue to face problems in performing their functions and duties properly (legislation, budget, and supervision) 
Proceedings of MICoMS 2017

\section{0}

because their positions in Aceh's House of Representatives are not in a strategic position; they have no strategic position, no high bargaining power.Thus, what happens is that woman is just an imitator of the decisions that are set, only as accessories and complement of the commission and the completeness of the board only.

When the composition between male and female legislators is not balanced, the concern related to the decisions taken is the impartiality for women; the voice of women in the legislature is not a priority and is considered unimportant, let alone, for example, it is related to the interests and rights, the women rights. Women legislators will lose in voting, for example, and be assured that what their wishes and aspirations will not be smoothly and easily accepted by male legislators and this will face them to more struggles in fighting for their rights in parliament. At every decision women are always defeated by male dominant groups, meaning that it will be very difficult for women to fulfill the rights and aspirations of their constituents.

The struggle of Acehnese women legislators in the local parliament does not stop when they have been elected as legislators; their struggle is long and they must be able to fulfill women's rights and, at the same time, fulfill their obligations as legislators. Therefore, women, legislators need to increase their capacity (human resource, knowledge, good and effective communication), have strong network strength, meaning that female legislators need to be able to build a network, both internally and externally.

Building internal network within the House of Representatives requires women legislators to be able to build good communication with all members in their commission, fraction, inter-commission, inter-party, faction, and male legislative members so that, in turn, there will be a political lobby that plays its part.Later, the dominant man will split and support the ideas, political ideas constructed by the woman, so that the political messages they convey will be well accommodated. In addition to internal networks, Acehnese female legislators must also be able to build an external networks with stakeholders, peer groups, NGOs that focus on women/women politics, academics, observers, experts and other community organizations, legislative women, and, in turn, this will be able to awaken their forces that will eventually be able to gain benefits as they have the power of network, their bargaining position in the House of Representatives will become stronger and the male legislators will allocate more attention when faced with the female legislators. Having a strong network inside and outside will make the political messages they convey to be well accommodated.

In general, weakness of women politicians in Indonesia may stem from the condition that Indonesia women are apathetic, silent, fail to conduct the things mentioned above; they are merely legislative members, without being able to make changes in the legislature, meaning that they are only the followers of the dominant group, the men.

\section{Conclusions and Suggestions}

\subsection{Conclusion}

(1) The presence of women in the local parliament of Aceh is not in accordance with the mandate of Affirmative Action law (30\%).

(2) The composition of women in Aceh's local parliament, especially in Aceh's House of Representatives was still not balanced.

(3) Female legislators do not occupy strategic positions in Aceh's House of Representatives, either in the Commission, Fractions, Legislation Body, Deliberation Body, Budget Body, or Special Committee. 
(1) There are great challenges for women legislators in fighting for rights and performing their duties and functions in local parliaments and, thus, legislators need to improve their capacity, knowledge and good communication.

(2) Build a strong network both internally (its political party, between parties, infractions, between fractions, between parties and with all other legislative members), and network with external parties (stakeholders, peer groups, NGOs, academics, observers, etc.).

\section{References}

2008., konstruksi realitas, Jakarta: KencanaPrenada Media Grop

Boserup, E (1984), Peran Wanita dalam Perkembangan Ekonomi, Yayasan Obor Indonesia, Jakarta.

Denzin, Norman K, dan Yvonna S. Lincoln, 2009., Handbook of Qualitative Research, edisi Bahasa Indonesia, PustakaPelajar, Yogyakarta.

Indriastuti, y (2015), disertasi program DoktorllmuKomunikasiUniversitasPadjadjarantentang manajemenkomunikasipolitikpolitisiperempuan (Studimanajemenkomunikasipolitikpe jabateksekutifperempuandalamkehidupanberpolitik diJawaTimur)

Harun, R dan Sumarno, (2006), Komunikasi Politik Sebagai Suatu Pengantar, Mandar Maju, Bandung.

\section{Corresponding author}

Ainol can be contacted at Ainol.mardhiah@unimal.ac.id 